\title{
Mediating Effect of Perceived Value on the Relationship between Brand Image and Customer Loyalty of Hair Salon
}

\author{
Yi-Ju Yeo ${ }^{1}$, Eun-Jun Park ${ }^{2 *}$ \\ ${ }^{1}$ Department of Beauty Design, Shin Ansan University, Ansan-si, Gyeonggi-do, Korea \\ ${ }^{2}$ Department of Hair and Makeup Design, College of Beauty Art, Seokyeong University, Seoul, Korea
}

\author{
*Corresponding author: Eun-Jun Park, \\ Department of Hair and Makeup Design, \\ College of Beauty Art, Seokyeong University, \\ 124 Seogyeong-ro, Seongbuk-gu, Seoul \\ 02713, Korea \\ Tel.: +82 29407846 \\ Email: ayamdream@hanmail.net
}

Received July 2, 2021

Revised July 21, 2021

Accepted August 5, 2021

Published September 30, 2021

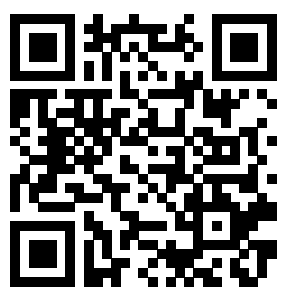

\begin{abstract}
Purpose: This study emphasizes brand image and perceived value by examining and identifying the mediating effect of the relationship between hair salons' brand images, perceived value, and customer loyalty. It aims to enhance the competitiveness of hair salon brands by providing the basic data necessary for the development and improvement of sales in professional hair salons. Methods: This study performed frequency analysis, reliability analysis, factor analysis, regression analysis, and mediation regression analysis, using SPSS 22.0 for 534 copies of data collected through questionnaires for adult men and women using hair salons. Results: The study results show that brand image significantly affected the perceived value and customer loyalty. Additionally, the perceived value significantly affected customer loyalty and partially mediated the relationship between brand image and customer loyalty. Conclusion: It is necessary to market factors with positive brand image effects for a hair salon, and customers should feel satisfied and unburdened. Additionally, to increase the salon's value, suitable unit prices for technology and services should be set instead of higher unit prices.
\end{abstract}

Keywords: Hair, Salon, Brand image, Perceived value, Customer loyalty

\section{Introduction}

경제발전과 함께 삶의 질이 향상되면서 미용서비스 산업은 꾸준히 성장하고 있으며, 소비자들은 빠른 정보와 풍부한 경험을 바탕으로 자신의 미적 욕구를 충족시킬 기술과 서비스를 제공해주는 곳을 끊임 없이 찾게 되었다. 미용서비스업은 다양한 수요층과 풍부한 수요량 을 가지고 있는 반면 종사자 수도 급증하고 있어 차별화 요소가 없으 면 고객만족을 이끌어 내기 힘든 상황이다(Jo \& Park, 2019).

최근에는 미용기업간의 기술격차가 점차 평준화 되어가고 있어 일 반적인 프로그램으로는 차별성을 두기가 더욱 어려워지고, 정보와 기술발달로 기업 간 경쟁요소와 소비자의 선택기준이 변화하고 있어 일반적인 서비스 외에도 기업의 가치를 결정짓는 브랜드 이미지를 더 욱 중요시하게 되었다(Lee \& Jin, 2015).

브랜드 이미지는 특정 브랜드가 소비자들에게 판매되고 사용되면 서 형성된 심리적 자용이라고 할 수 있으며, 작게는 정서적 반응, 크 게는 매출에 영향을 끼치는 정서 작용을 총칭한다 Song (2021). 브랜
드 이미지는 소비자가 기술과 서비스의 질적 특성에 충분한 식별능력 을 가지지 못하는 경우 구매동기나 판별 기준을 제공하고, 구매결정 에 결정적인 역할을 하기 때문에 긍정적인 브랜드 이미지 형성은 매 우 중요하다고 할 수 있다(Kim et al., 2015). 헤어 살롱의 경우 브랜 드 이미지는 고객의 소비 가치와 밀접하게 연관되어 있다. 고객이 지 각하는 가치가 높을수록 브랜드 이미지가 높아진다고 볼 수 있으며 고객 충성도 또한 높일 수 있게 된다(Lee \& Hwang, 2014). 일반적 으로 고객에게 전달된 가치란, 고객의 욕구를 충족시키는 기술과 서 비스의 전반적인 능력에 대한 고객의 평가를 의미하고, 지각된 가치 는 지불한 것과 얻은 것의 차이라고 할 수 있으며, 개개인마다 관점 이 다르기 때문에 주관적인 가치라고 볼 수 있다(Choi et al., 2019).

관련된 선행연구를 살펴보면 Lee et al. (2015)은 헤어 미용기업의 선호브랜드별 브랜드 이미지와 구매의도에 대해 연구하여 브랜드 이 미지의 중요성을 강조하고 구매의도와 유의미한 영향관계에 있음을 확인하였고, Jeong \& Kim (2020)은 해외직접구매의 브랜드 이미지 가 지각된 가치에 유의미한 정의 영향을 미치는 것을 확인하였으며, 
Jo et al. (2019)는 디저트 카페의 브랜드 이미지가 지각된 가치에 미 치는 영향을 연구하여 유의미한 정(+)의 영향 관계이며 긍정적 브랜 드 이미지는 소비자의 지출 비용에 대한 합리적 인식이 될 수 있음을 밝힌 바 있다. 또한 $\operatorname{Kim} \& \operatorname{Kim}(2010)$ 의 연구에서 브랜드 이미지가 고객만족과 충성도에 미치는 영향을 연구하여 유의미한 영향관계에 있음을 확인하였고, 브랜드 이미지가 고객 충성도와 밀접한 관련이 있음을 시사하였다. Lyu (2018)도 마찬가지로 브랜드 인지도와 고객 충성도의 관계를 연구하여, 두 변인이 서로 유의미한 영향 관계에 있 으며, 브랜드에 대한 인식은 막연하게 일어나는 것이 아니라 경험을 바탕으로 브랜드에 대한 충성을 포함한 태도라고 주장하였다. Jung $\&$ Lee (2016)은 지각된 가치와 고객 충성도에 대해 연구하여 지각된 가치가 고객 충성도에 유의미한 정(+)의 영향을 미치고 있음을 확인 하였다.

이렇듯 브랜드 이미지와 지각된 가치는 서로 유의미한 관계를 가 지고 있으며 이는 고객 충성도와 밀접한 관련이 있음을 알 수 있다. 따라서 헤어 살롱의 궁극적 목표인 고객 충성도를 높이기 위해서 브 랜드 이미지와 지각된 가치에 대해 중요하게 다루어 져야할 필요가 있다.

따라서 본 연구는 헤어 살롱 브랜드 이미지가 소비자의 지각된 가 치, 고객 충성도의 관계를 알아보고, 헤어 살롱 브랜드 이미지와 고 객 충성도의 관계에서 지각된 가치의 매개효과를 파악하고자 한다. 이러한 연구를 통해 브랜드 이미지와 지각된 가치의 중요성을 강조하 고 전문적인 헤어 살롱의 발전과 매출 향상을 위해 필요한 기초 자료 를 제공하여 헤어 살롱 브랜드의 경쟁력을 높이는데 그 목적이 있다.

\section{Methods}

\section{1. 연구대상 및 자료수집}

본 연구는 헤어 살롱을 이용하는 성인 남녀를 대상으로 설정하였 다. 자료의 수집방법으로 자기기입식 설문지법이 사용되었으며, 예 비조사와 본 조사를 통해 연구문제를 해결하는데 필요한 자료가 수집 되었다.

2021년 3월 1일부터 3 월 10 일까지 총 30 부의 예비조사를 통해 측 정도구인 설문지의 구성과 내용을 수정 및 보완한 후 본 조사를 실시 하였다. 본 조사는 2021년 3월 11일부터 2021년 5월 10일까지 실시 되었고 총 540 부의 설문지를 배포하여 수거된 535 부의 설문지 중 분
석에 사용되기 불충분하다고 판단되는 1 부의 설문지를 제외한 534 부 가 최종 분석 자료로 사용되었다.

\section{2. 측정항목 및 내용}

본 연구는 자료의 수집을 위해 설문지법이 사용되었다. 설문 문항 은 크게 일반적 특성(5), 브랜드 이미지(8), 지각된가치(5), 고객충성 도(8)의 26 문항으로 구성되었으며, 선행연구의 설문문항 및 구성개 념을 인용 및 응용하였다. 본 연구에 사용된 모든 리커트 척도는 '1: 전혀 그렇지 않다'에서 ' 5 :매우 그렇다'까지의 5 점 리커트 척도가 사 용되었다. 설문지의 구체적인 내용은 Table 1 과 같다.

\section{3. 분석방법}

수집한 자료를 분석하여 연구문제를 검정하기 위해 SPSS 22.0 (IBM, USA), analysis of moment structure (AMOS) 21.0 (IBM)이 사용되었고, 자료의 분석방법은 가설에 맞게 순차적으로 적용되었으 며 다음과 같다.

첫째, 조사대상의 일반적 특성을 알아보기 위해 빈도분석을 하였 다. 둘째, 헤어 살롱의 브랜드 이미지, 지각된 가치, 고객 충성도의 타당성 및 신뢰성 평가를 위해 요인분석을 시행하였고(주성분분석, 베리멕스 사용), Cronbach's $\alpha$ 을 이용한 신뢰도 분석을 시행하였다. 셋째, 헤어 살롱 브랜드 이미지, 지각된 가치, 고객 충성도의 관계를 알아보기 위해 회귀분석을 실시하였다. 넷째, 헤어 살롱의 브랜드 이 미지와 고객 충성도의 관계에서 지각된 가치의 매개효과를 알아보기 위해 매개 회귀분석을 실시하였다. 회귀분석의 변수 투입 방법은 입 력 방식을 사용하였다.

\section{4. 연구모형 및 연구가설}

Jeong \& Kim (2020)의 연구에서 브랜드 이미지가 지각된 가치에 유의미한 영향을 미치고 있음을 확인하였으며, Jo et al. (2019)의 연 구에서는 카페의 브랜드 이미지가 지각된 가치에 유의미한 영향을 미 치며 긍정적 브랜드 이미지 형성은 소비자가 합리적 소비로 인식할 수 있게 해주는 중요한 요인이라고 보았다. 또한 Kim \& Kim (2010) 의 연구에서는 와인 바의 브랜드 이미지가 고객 충성도에 유의한 영 향을 미치고 있음을 확인하였고, 재방문 의도와 유의미한 영향관계 에 있음을 확인하였다. Lyu (2018)의 연구에서도 화장품 기업의 브 랜드 이미지와 고객 충성도의 관계를 연구하여 유의미한 영향관계임 을 확인하였다. Kang \& Park (2016)는 병원의 브랜드 이미지와 고

Table 1. Configuration of a questionnaire

\begin{tabular}{lll}
\hline Research variables & Scale (No. of questions) & Quotation \& applied data \\
General characteristics & Nominal scale (5) & Organization of researchers \\
Brand image & 5-point Likert scale (8) & Jo \& Park (2019), Lee \& Jin (2015), Kim et al., (2015), Oh (2021) \\
Customer loyalty & 5-point Likert scale (8) & Kook et al., (2016), Woo \& Park (2017) \\
Perceived value & 5-point Likert scale (5) & Lee \& Na (2021), Choi et al., (2019) \\
\hline
\end{tabular}




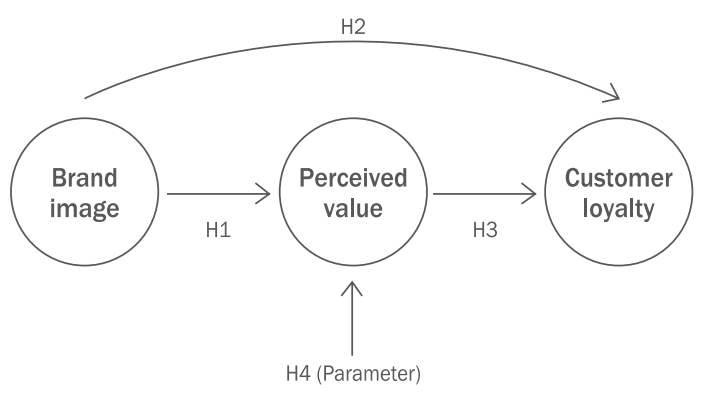

Figure 1. Research model and hypothesis.

Hypothesis 1 . The brand image of a hair salon will have a positive $(+)$ effect on the perceived value.

Hypothesis 2. The brand image of a hair salon will have a positive $(+)$ effect on customer loyalty.

Hypothesis 3. The perceived value of a hair salon will have a positive $(+)$ effect on customer loyalty.

Hypothesis 4. The perceived value in the relationship between brand image and customer loyalty of hair salons will play a mediating role.
객 충성도의 관계를 연구하여 두 변수가 유의미한 영향관계임을 확인 하였고 충성도 향상을 위해서는 브랜드 이미지가 중요한 요인임을 강 조하였다. Choi et al. (2015)은 커피전문점의 지각된 가치가 고객 충 성도에 미치는 영향에 대해 연구하였고, 지각된 가치의 하위요인은 기능적 가치와 감정적 가치로 분류하였으며, 고객 충성도는 재방문 의사와 추천의도로 분류하였다. 연구결과 지각된 가치가 고객 충성 도에 유의미한 영향을 미치는 것으로 확인되었다. Lee \& Kim (2019) 은 프로축구의 지각된 가치와 재관람의도, 구전의도의 관계를 연구 하였고, 모두 유의미한 영향을 미치는 것으로 나타났다. Lee (2019) 의 연구에서도 향토관광음식점의 지각된 가치가 고객 만족과 재방문 의도에 미치는 영향을 연구하여 유의미한 정(+)의 영향을 미치는 것 을 확인한 바 있다. 또한 Jeong \& $\mathrm{Kim}$ (2020)의 해외 직접구매의 브 랜드 이미지와 만족도의 관계에서 지각된 가치의 완전매개 효과가 확 인되었다.

이러한 선행연구를 근거로 본 연구의 가설을 설정하였다. 연구가 설에 따른 연구모형은 다음 Figure 1과 같다.

가설 1. 헤어 살롱의 브랜드 이미지는 지각된 가치에 정(+)의 영향

Table 2. General characteristics

$(\mathrm{N}=534, \%)$

\begin{tabular}{|c|c|c|c|}
\hline & \multirow{2}{*}{ Item } & \multicolumn{2}{|c|}{ Sum } \\
\hline & & $\mathrm{N}$ & $\%$ \\
\hline \multirow{2}{*}{ Gender } & Man & 175 & 32.8 \\
\hline & Woman & 359 & 67.2 \\
\hline \multirow{4}{*}{ Age } & 20 's & 97 & 18.1 \\
\hline & 30 's & 160 & 30.0 \\
\hline & 40 's & 135 & 25.3 \\
\hline & over 50 & 142 & 26.6 \\
\hline \multirow{3}{*}{ Marital status } & Single & 253 & 47.4 \\
\hline & Married & 260 & 48.7 \\
\hline & Etc. & 21 & 3.9 \\
\hline \multirow{9}{*}{ Occupation } & Official & 32 & 6.0 \\
\hline & Clerical/Technical & 76 & 14.1 \\
\hline & Profession & 69 & 12.9 \\
\hline & Sales/Service jobs & 89 & 16.7 \\
\hline & Self-employed & 41 & 7.7 \\
\hline & Housewife & 62 & 11.6 \\
\hline & Production/Technician & 55 & 10.3 \\
\hline & Student & 54 & 10.1 \\
\hline & Etc & 56 & 10.5 \\
\hline \multirow{5}{*}{ Monthly income } & 1 million KRW - less than 2 million KRW & 37 & 6.9 \\
\hline & 2 million KRW - less than 3 million KRW & 263 & 49.3 \\
\hline & 3 million KRW - less than 4 million KRW & 176 & 33.0 \\
\hline & 4 million KRW - less than 5 million KRW & 45 & 8.4 \\
\hline & Over 500 million KRW & 13 & 2.4 \\
\hline Sum & & 534 & 100 \\
\hline
\end{tabular}


Table 3. Relevance and credibility of brand image

\begin{tabular}{|c|c|c|c|}
\hline \multirow[b]{2}{*}{ Questionnaire } & Factor 1 & Factor 2 & \multirow[b]{2}{*}{ Commonality } \\
\hline & $\begin{array}{c}\text { Symbolic } \\
\text { image }\end{array}$ & $\begin{array}{l}\text { Functional } \\
\text { image }\end{array}$ & \\
\hline This hair salon has a differentiated image from other brands. & 0.783 & -0.017 & 0.613 \\
\hline You can easily remember the logo or symbol (concept) of this hair salon brand. & 0.745 & 0.219 & 0.603 \\
\hline The brand I use has a unique image that is different from other brands. & 0.740 & 0.095 & 0.556 \\
\hline This hair salon brand feels familiar. & 0.692 & 0.288 & 0.563 \\
\hline This hair salon is professional and skillful. & 0.068 & 0.755 & 0.574 \\
\hline The designers of this hair salon have reliable skills. & 0.063 & 0.707 & 0.504 \\
\hline Customers have a good reputation for the brand of this hair salon. & 0.159 & 0.687 & 0.497 \\
\hline This hair salon pursues fashion. & 0.394 & 0.519 & 0.424 \\
\hline Eigenvalue & 2.384 & 1.951 & \\
\hline Description variable (\%) & 29.797 & 24.384 & \\
\hline Cumulative variance (\%) & 29.797 & 54.181 & \\
\hline Cronbach's $\alpha$ & 0.754 & 0.643 & \\
\hline
\end{tabular}

Table 4. Validity and reliability of perceived value

\begin{tabular}{lcc}
\hline Questionnaire & Factor 1 & Commonality \\
\cline { 2 - 3 } This hair salon is reasonably priced compared to other salons. & Perceived price & 0.793 \\
I think the service fee of this hair salon is reasonable. & 0.764 & 0.629 \\
In this hair salon, the price image matches the actual treatment amount. & 0.757 & 0.584 \\
This hair salon is priced after sufficient price consultation. & 0.713 & 0.573 \\
The price of this hair salon is similar to what I thought. & 0.691 & 0.478 \\
Eigenvalue & 2.771 \\
Description variable (\%) & 55.412 \\
Cumulative variance (\%) & 55.412 \\
Cronbach's $\alpha$ & 0.793 \\
\hline
\end{tabular}

Table 5. Relevance and reliability of customer loyalty

\begin{tabular}{|c|c|c|c|}
\hline \multirow[b]{2}{*}{ Questionnaire } & Factor 1 & Factor 2 & \multirow[b]{2}{*}{ Commonality } \\
\hline & $\begin{array}{l}\text { Word of } \\
\text { mouth }\end{array}$ & $\begin{array}{l}\text { Intention to } \\
\text { revisit }\end{array}$ & \\
\hline I recommend this hair salon to my friends. & 0.916 & 0.103 & 0.850 \\
\hline I am willing to recommend this hair salon to others. & 0.876 & 0.158 & 0.793 \\
\hline I would invite my friends to use this hair salon. & 0.816 & 0.315 & 0.765 \\
\hline I highly recommend this hair salon. & 0.700 & 0.303 & 0.652 \\
\hline The hair salon designers have excellent technical skills and will come back again. & 0.055 & 0.816 & 0.670 \\
\hline If the current service is available, we will visit again. & 0.255 & 0.692 & 0.544 \\
\hline The hair salon designer's service skills are excellent and will come back again. & 0.159 & 0.649 & 0.446 \\
\hline I will use my current hair salon again next time. & 0.333 & 0.643 & 0.524 \\
\hline Eigenvalue & 2.967 & 2.276 & \\
\hline Description variable (\%) & 37.084 & 28.455 & \\
\hline Cumulative variance (\%) & 37.084 & 65.539 & \\
\hline Cronbach's $\alpha$ & 0.887 & 0.713 & \\
\hline
\end{tabular}


을 미칠 것이다.

가설 2. 헤어 살롱의 브랜드 이미지는 고객 충성도에 정(+)의 영향 을 미칠 것이다.

가설 3. 헤어 살롱의 지각된 가치는 고객 충성도에 정(+)의 영향을 미칠 것이다.

가설 4. 헤어 살롱의 브랜드 이미지와 고객 충성도의 관계에서 지 각된 가치는 매개역할을 할 것이다.

\section{Results and Discussion}

\section{1. 조사대상의 일반적 특성}

조사대상의 일반적 사항을 알아보기 위해 빈도분석을 실시한 결과 는 다음 Table 2 와 같다.

성별은 여성 $67.2 \%$, 남성 $32.8 \%$ 로 여성이 높게 나타났다. 연령 의 경우 30 대가 $30.0 \%$ 로 가장 높게 나타났고, 다음은 50 대 이상 $26.6 \%, 40$ 대 $25.3 \%, 20$ 대 $18.1 \%$ 순으로 나타났다. 결혼여부는 기혼 이 $48.7 \%$ 로 가장 높게 나타났고, 다음은 미혼 $47.4 \%$, 기타 $3.9 \%$ 순 으로 나타났다. 직종을 알아본 결과 판매/서비스직이 $16.7 \%$ 로 가장 높게 나타났고, 다음은 사무/기술직 $14.1 \%$, 전문직 $12.9 \%$, 전업주부 $11.6 \%$, 기타 $10.5 \%$, 생산/기술직 $10.3 \%$, 학생 $10.1 \%$, 자영업 $7.7 \%$, 공무원 $6.0 \%$ 순으로 나타났다. 월 소득의 경우 200 만 원에서 300 만 원 미만이 $49.3 \%$ 로 가장 높게 나타났고, 다음은 300 만 원에서 400 만 원 미만 $33.0 \%, 400$ 만 원에서 500 만 원 미만 $8.4 \%, 100$ 만 원에서 200 만 원 미만 $6.9 \%, 500$ 만 원 이상 $2.4 \%$ 순으로 나타났다.

\section{2. 각 변수들의 타당성 및 신뢰도}

\section{1) 브랜드 이미지의 타당성 및 신뢰도}

브랜드 이미지 문항의 타당성을 검증하기 위해 요인분석 한 결과 Table 3 과 같이 두 개의 요인이 도출되었다. Bartlett의 단위행렬 점 검 결과 $=931.491(\mathrm{df}=28, \mathrm{Sig}=0.000), \mathrm{KMO}$ 값 0.788로 나타났으 며, 공통성은 0.497 이상으로 나타났다.

첫 번째 요인은 '상징적 이미지' 요인으로 요인적재값은 0.6920.783 로 나타났으며, 고유값은 2.384 , 분산설명비율은 $19.7 \%$ 로
나타났다. 두 번째 요인은 '기능적 이미지' 요인으로 요인적재값 은 0.519-0.755로 나타났으며, 고유값은 1.951 , 분산설명비율은 $24.3 \%$ 로 나타났다.

요인분석 결과 도출된 두 개의 요인이 전체 분산의 $54.1 \%$ 이상 설 명되고 있는 것으로 나타났다.

신뢰도 검증 결과, 두 요인 모두 신뢰도 계수인 Cronbach's $\alpha$ 가 0.643-0.754로 나타나, 신뢰성에는 문제가 없는 것으로 나타났다.

\section{2) 지각된 가치의 타당성 및 신뢰도}

지각된 가치 문항의 타당성을 검증하기 위해 요인분석 한 결과 Table 4와 같이 하나의 요인이 도출되었다. Bartlett의 단위행렬 점검 결과 $=771.537(\mathrm{df}=10, \mathrm{Sig}=0.000), \mathrm{KMO}$ 값 0.793 로 나타났으며, 공통성은 0.478 이상, 전체 설명력은 $55.4 \%$ 로 나타났다.

신뢰도 검증 결과, 신뢰도 계수인 Cronbach's $\alpha$ 가 0.793 로 나타 나, 신뢰성에는 문제가 없는 것으로 나타났다.

\section{3) 고객 충성도의 타당성 및 신뢰도}

고객 충성도 문항의 타당성을 검증하기 위해 요인분석 한 결과 Table 5 와 같이 두 개의 요인이 도출되었다. Bartlett의 단위행렬 점 검 결과 $=1916.715(\mathrm{df}=28, \mathrm{Sig}=0.000), \mathrm{KMO}$ 값 0.851 로 나타났으 며, 공통성은 0.446 이상으로 나타났다.

첫 번째 요인은 '구전의도' 요인으로 요인적재값은 0.700-0.916로 나타났으며, 고유값은 2.967 , 분산설명비율은 $37.0 \%$ 로 나타났다. 두 번째 요인은 '재방문의도' 요인으로 요인적재값은 0.643-0.816로 나 타났으며, 고유값은 2.276 , 분산설명비율은 $28.4 \%$ 로 나타났다.

요인분석 결과 도출된 두 개의 요인이 전체 분산의 $65.5 \%$ 이상 설 명되고 있는 것으로 나타났다.

신뢰도 검증 결과, 두 요인 모두 신뢰도 계수인 Cronbach's $\alpha$ 가 0.713-0.887로 나타나, 신뢰성에는 문제가 없는 것으로 나타났다.

\section{3. 가설의 검증}

1) 가설 1. 헤어 살롱 브랜드 이미지가 지각된 가치에 미치는 영향 브랜드 이미지가 지각된 가격에 미치는 영향에 대한 회귀분석 결 과는 Table 6 과 같다.

Table 6. Effect of brand image on perceived price

\begin{tabular}{|c|c|c|c|c|c|c|}
\hline $\begin{array}{l}\text { Dependent variable } \\
\text { (perceived value) }\end{array}$ & $\begin{array}{l}\text { Independent } \\
\text { variable } \\
\text { (brand image) }\end{array}$ & B & SE B & $\beta$ & $t$ & $p$ \\
\hline \multirow{3}{*}{ Perceived value } & (Constant) & 0.000 & 0.034 & & 0.000 & 1.000 \\
\hline & Symbolic image & 0.393 & 0.034 & 0.393 & $11.561^{* * *}$ & 0.000 \\
\hline & Technical image & 0.483 & 0.034 & 0.483 & $14.210^{* * *}$ & 0.000 \\
\hline \multicolumn{7}{|c|}{$\operatorname{adj} \mathrm{R}^{2}=0.385, F=167.790, p=0.000^{* * *}$} \\
\hline
\end{tabular}

$\mathrm{B}$, unstandardized coefficient; SE B, standard error of estimate; $\beta$, standardized coefficient; $t, t$-value; $\mathrm{R}^{2}$, correlation coefficient; $F$, F-value; ${ }^{* * *} p<0.001$. 
지각된 가격은 브랜드 이미지의 상징적 이미지, 기능적 이미지 요인이 유의미하게 $(p<0.001)$ 영향을 미치는 것으로 나타났고 상징 적 이미지, 기능적 이미지 변수가 지각된 가격 요인을 예측하는데 $38.5 \%$ 의 설명력을 갖는 것으로 나타났다. 독립변수의 영향력을 살펴 보면 기능적 이미지( $\beta=0.483)$, 상징적 이미지( $\beta=0.393)$ 순으로 유의 미하게 정(+)적으로 영향을 미치는 것으로 나타났다. 이는 상징적 이
미지, 기능적 이미지가 높아질수록 지각된 가격도 높아지고 있음을 의미하며, Jeong \& Kim (2020), Jo et al. (2019)의 연구와 일치하는 결과로 브랜드 이미지와 지각된 가치가 밀접한 관련이 있음을 확인할 수 있다. 따라서 가설 1 은 채택되었다.

2) 가설 2. 헤어 살롱 브랜드 이미지가 고객 충성도에 미치는 영향

Table 7. How brand image affects customer loyalty

\begin{tabular}{|c|c|c|c|c|c|c|}
\hline $\begin{array}{l}\text { Dependent variable } \\
\text { (customer loyalty) }\end{array}$ & $\begin{array}{l}\text { Independent } \\
\text { variable } \\
\text { (brand image) }\end{array}$ & B & SE B & $\beta$ & $t$ & $p$ \\
\hline \multirow{3}{*}{ Word of mouth } & (Constant) & 0.000 & 0.037 & & 0.000 & 1.000 \\
\hline & Symbolic image & 0.490 & 0.037 & 0.490 & $13.256^{* * *}$ & 0.000 \\
\hline & Functional image & 0.182 & 0.037 & 0.182 & $4.912^{* * *}$ & 0.000 \\
\hline \multicolumn{7}{|c|}{$\operatorname{adj} \mathrm{R}^{2}=0.271, F=99.921, p=0.000^{* * *}$} \\
\hline \multirow{3}{*}{ Intention to revisit } & (Constant) & 0.000 & 0.035 & & 0.000 & 1.000 \\
\hline & Symbolic image & 0.061 & 0.035 & 0.061 & 1.743 & 0.082 \\
\hline & Functional image & 0.595 & 0.035 & 0.595 & $17.107^{* * *}$ & 0.000 \\
\hline \multicolumn{7}{|c|}{$\operatorname{adj} \mathrm{R}^{2}=0.355, F=147.849, p=0.000^{* * *}$} \\
\hline
\end{tabular}

${ }^{* * *} p<0.001 ; \mathrm{B}$, unstandardized coefficient; SE B, standard error of estimate: $\beta$, standardized coefficient; $\mathrm{R}^{2}$, correlation coefficient.

Table 8. Effect of perceived value on customer loyalty

\begin{tabular}{|c|c|c|c|c|c|c|}
\hline $\begin{array}{l}\text { Dependent variable } \\
\text { (customer loyalty) }\end{array}$ & $\begin{array}{l}\text { Independent } \\
\text { variable } \\
\text { (perceived price) }\end{array}$ & B & SE B & $\beta$ & $t$ & $p$ \\
\hline \multirow{2}{*}{ Word of mouth } & (Constant) & 0.000 & 0.039 & & 0.000 & 0.000 \\
\hline & Perceived value & 0.410 & 0.040 & 0.410 & $10.382^{* * *}$ & $0.000^{* * *}$ \\
\hline \multicolumn{7}{|c|}{$\operatorname{adj} \mathrm{R}^{2}=0.167, F=107.782, p=0.000^{* * *}$} \\
\hline \multirow{2}{*}{ Intention to revisit } & (Constant) & 0.000 & 0.038 & & 0.000 & 1.000 \\
\hline & Perceived value & 0.500 & 0.038 & 0.500 & $13.311^{* * *}$ & 0.000 \\
\hline \multicolumn{7}{|c|}{ adj $\mathrm{R}^{2}=0.248, F=177.181, p=0.000^{* * *}$} \\
\hline
\end{tabular}

Table 9. Mediating Effect of perceived value on the Relationship between Brand Image and Customer Loyalty

\begin{tabular}{|c|c|c|c|c|c|c|}
\hline & Antecedent variable & Outcome variable & $\beta$ & $t$ & $\operatorname{adj} R^{2}$ & $F$ \\
\hline \multirow{2}{*}{ Stage 1} & Symbolic image & \multirow{2}{*}{ Perceived value } & 0.039 & $11.561^{* * *}$ & \multirow{2}{*}{0.385} & \multirow{2}{*}{$167.790^{* *}$} \\
\hline & Functional image & & 0.483 & $14.210^{* * *}$ & & \\
\hline \multirow{4}{*}{ Stage 2} & \multirow{2}{*}{ Symbolic image } & \multirow{2}{*}{ Word of mouth } & 0.490 & $13.256^{* * *}$ & \multirow{2}{*}{0.271} & \multirow{2}{*}{$99.921^{* * *}$} \\
\hline & & & 0.182 & $4.912^{* * *}$ & & \\
\hline & \multirow{2}{*}{ Functional image } & \multirow{2}{*}{ Intention to revisit } & 0.061 & 1.743 & \multirow{2}{*}{0.355} & \multirow{2}{*}{$147.849^{* *}$} \\
\hline & & & 0.595 & $17.107^{* * *}$ & & \\
\hline \multirow{2}{*}{ Stage 3} & \multirow{2}{*}{ Perceived value } & Word of mouth & 0.410 & $10.382^{* * *}$ & 0.167 & $107.782^{* * *}$ \\
\hline & & Intention to revisit & 0.500 & $13.311^{* * *}$ & 0.248 & $177.181^{* * *}$ \\
\hline \multirow{4}{*}{ Stage 4} & \multirow{2}{*}{ Symbolic image perceived value } & & 0.389 & $9.833^{* * *}$ & \multirow{2}{*}{0.294} & \multirow{2}{*}{$11.929^{* *}$} \\
\hline & & & 0.258 & $6.509^{* * *}$ & & \\
\hline & \multirow{2}{*}{ Functional image perceived value } & Word of mouth & -0.160 & $-3.984^{* * *}$ & \multirow{2}{*}{0.269} & \multirow{2}{*}{$99.001^{* * *}$} \\
\hline & & & 0.563 & $13.976^{* * *}$ & & \\
\hline
\end{tabular}

${ }^{* * *} p<0.001 ; B$, unstandardized coefficient; SE B, standard error of estimate; $\beta$, standardized coefficient; $\mathrm{R}^{2}$, correlation coefficient. 
브랜드 이미지가 고객 충성도에 미치는 영향에 대한 회귀분석 결 과는 Table 7과 같다.

고객 충성도의 하위요인인 구전의도는 브랜드 이미지의 상징적 이 미지, 기능적 이미지 요인이 유의미하게 $(p<0.001)$ 영향을 미치는 것 으로 나타났고 상징적 이미지, 기능적 이미지 변수가 구전의도 요 인을 예측하는데 $27.1 \%$ 의 설명력을 갖는 것으로 나타났다. 독립변 수의 영향력을 살펴보면 상징적 이미지 $(\beta=0.490)$, 기능적 이미지 $(\beta=0.182)$ 순으로 유의미하게 정 $(+)$ 적으로 영향을 미치는 것으로 나 타났다. 이는 상징적 이미지, 기능적 이미지가 높아질수록 구전의도 도 높아지고 있음을 의미한다.

고객 충성도의 하위요인인 재방문의도는 브랜드 이미지의 기능적 이미지 요인이 유의미하게 $(p<0.001)$ 영향을 미치는 것으로 나타났고 기능적 이미지 변수가 재방문의도 요인을 예측하는데 $35.5 \%$ 의 설명 력을 갖는 것으로 나타났다. 독립변수의 영향력을 살펴보면 기능적 이미지( $\beta=0.595)$ 으로 유의미하게 정 $(+)$ 적으로 영향을 미치는 것으 로 나타났다. 이는 기능적 이미지가 높아질수록 재방문의도도 높아 지고 있음을 의미한다. Kim \& Oh (2018)와 Kang \& Park (2016)의 연구에서도 브랜드 이미지가 고객 충성도에 유의미한 정(+)의 영향 을 미친다고 나타나 본 연구 결과를 뒷받침 해주고 있다. 따라서 가 설 2는 채택되었다.

\section{3) 가설 3. 헤어 살롱의 지각된 가치가 고객 충성도에 미치는 영향}

지각된 가치가 고객 충성도에 미치는 영향에 대한 회귀분석 결과 는 Table 8과 같다.

고객 충성도의 하위요인인 구전의도는 지각된 가치 요인이 유의 미하게 $(p<0.001)$ 영향을 미치는 것으로 나타났고 지각된 가치 변수 가 구전의도 요인을 예측하는데 $16.7 \%$ 의 설명력을 갖는 것으로 나타 났다. 독립변수의 영향력을 살펴보면 지각된 가치 $(\beta=0.410)$ 으로 유 의미하게 정(+)적으로 영향을 미치는 것으로 나타났다. 이는 지각된 가치가 높아질수록 구전의도도 높아지고 있음을 의미한다.

고객 충성도의 하위요인인 재방문의도는 지각된 가치 요인이 유 의미하게 $(p<0.001)$ 영향을 미치는 것으로 나타났고 지각된 가치 변 수가 재방문의도 요인을 예측하는데 $24.8 \%$ 의 설명력을 갖는 것으로 나타났다. 독립변수의 영향력을 살펴보면 지각된 가치( $\beta=0.500)$ 으 로 유의미하게 정 $(+)$ 적으로 영향을 미치는 것으로 나타났다. 이는 지 각된 가치가 높아질수록 재방문의도도 높아지고 있음을 의미하며, Choi et al., (2015)의 지각된 가치와 고객 충성도에 대한 연구에서 도 두 변수의 유의미한 영향관계를 확인하여 본 연구결과와 유사하였 다. 따라서 가설 3 은 채택되었다.

4) 헤어 살롱 브랜드 이미지와 고객 충성도의 관계에서 지각된 가 치의 매개효과

위 회귀분석에서 매개효과 검증에 필요한 1 단계, 2 단계, 3 단계 의 조건을 모두 만족시킨 변수들의 매개효과 검증을 실시한 결과는
Table 9와 같다.

브랜드 이미지의 하위요인인 상징적 이미지, 기능적 이미지와 구 전의도의 관계에서 지각된 가치의 매개 역할에 대한 분석결과는 매개 효과 검증에 필요한 1 단계, 2 단계, 3 단계의 조건을 모두 만족시켰으 므로, 4 단계 검증에서 2 단계에서 나타난 독립변인의 표준화된 회귀 계수( $\beta$ )값을 비교하여 매개효과를 확인하였다.

상징적 이미지가 구전의도에 미치는 영향관계는 2 단계에서 통 계적으로 유의미하며, 4 단계에서 지각된 가치를 투입했을 때, $\beta=0.490>\beta=0.389$ 로 회귀계수 값이 줄어들었을 뿐만 아니라 통계적 유의성이 확인되었으므로 지각된 가치의 매개효과가 확인되었다.

기능적 이미지가 구전의도에 미치는 영향관계는 2 단계에서 통 계적으로 유의미하며, 4 단계에서 지각된 가치를 투입했을 때, $\beta=0.182>\beta=-0.160$ 로 회귀계수 값이 줄어들었을 뿐만 아니라 통계 적 유의성이 확인되었으므로 지각된 가치의 매개효과가 확인되었다.

브랜드 이미지와 재방문 의도의 영향관계는 2 단계의 조건을 충족 시키지 못하였으므로 지각된 가치의 매개효과가 있다고 판단할 수 없 다.

Jeong \& Kim (2020)는 브랜드 이미지가 만족도와 구매의사의 관 계에서 지각된 가치가 부분매개 효과가 있음을 확인하여 본 연구결과 와 유사하게 나타났다. 따라서 가설 4는 부분채택 되었다.

\section{Conclusion}

본 연구는 헤어 살롱 브랜드 이미지와 지각된 가치, 고객 충성도의 관계를 알아보고, 헤어 살롱 브랜드 이미지와 고객 충성도의 관계에 서 지각된 가치의 매개효과를 파악하여 브랜드 이미지와 지각된 가치 의 중요성을 강조하고 전문적인 헤어 살롱의 발전과 매출 향상을 위 해 필요한 기초 자료를 제공하여 헤어 살롱 브랜드의 경쟁력을 높이 는 것을 목적으로 하였다.

헤어 살롱을 이용하는 성인 남녀를 대상으로 설문지법을 통해 수 집된 자료 534 부는 SPSS 22.0 을 사용하여 빈도분석, 요인분석, 신뢰 도분석, 회귀분석, 매개회귀분석을 실시하였다.

연구결과는 다음과 같았다. 첫째, 성별은 여성이 높게 나타났다. 연령의 경우 30 대가 가장 높게 나타났고, 결혼여부는 기혼이 가장 높 게 나타났다. 직종을 알아본 결과 판매/서비스직이 가장 높게 나타 났고, 월 소득의 경우 200 만 원에서 300 만 원 미만이 가장 높게 나 타났다. 둘째, 각 설문 문항들을 요인분석한 결과 헤어 살롱 브랜드 이미지는 상징적 이미지, 기능적 이미지의 두 가지 요인이 도출되었 고 전체 설명력은 $54.1 \%$ 이상, 신뢰도계수는 0.643 이상으로 나타났 다. 지각된 가치는 하나의 요인이 도출되었고 전체 설명력은 $55.4 \%$ 이상, 신뢰도계수는 0.793 이상으로 나타났다. 고객 충성도 요인은 구전의도, 재방문의도의 두 가지 요인이 도출되었고 전체 설명력은 $65.5 \%$ 이상, 신뢰도계수는 0.887 이상으로 나타났다. 셋째, 가설검 
증 결과 헤어 살롱 브랜드 이미지는 지각된 가치와 고객 충성도에 유 의미한 정(+)의 영향을 미치는 것으로 나타났고, 지각된 가치가 고객 충성도에 유의미한 정(+)의 영향을 미치는 것으로 나타나 가설은 채 택 되었다. 헤어 살롱 브랜드 이미지와 고객 충성도의 관계에서 지각 된 가치의 매개 효과를 알아본 결과 가설은 부분채택 되었다. 이렇듯 헤어 살롱 브랜드 이미지와 지각된 가치, 고객 충성도는 서로 유의한 영향관계임을 확인하였으며, 연구 결과에 따른 시사점은 다음과 같 다.

첫째, 브랜드 이미지가 높아질수록 지각된 가치도 높아짐을 확인 하였다. 따라서 헤어 살롱의 브랜드 이미지에 긍정적인 효과를 줄 수 있는 요소들을 마케팅 할 필요가 있다. 매장의 분위기를 고급스럽게 연출하고, 직원의 유니폼이나 품행에도 신경 써야 할 것이다. 또한 차와 다과에 품질을 높여 브랜드 이미지를 한층 더 끌어올릴 수 있을 것이다. 이러한 상징적 이미지 외에도 기술적 이미지 향상을 위해 직 원들의 재교육에도 꾸준히 투자해야 할 것이다. 이러한 노력은 헤어 살롱을 방문하는 고객들이 지각하는 소비 가치에 긍정적인 역할을 할 것이다. 둘째, 브랜드 이미지가 고객 충성도에 정(+)의 영향을 미치 는 것으로 나타났다. 고객 충성도를 높이기 위해서는 참신한 고객 관 리 프로그램 도입이 도움이 될 것으로 사료된다. 지금까지의 평범한 고객관리 프로그램 보다는 1 대 1 맞춤형 관리 프로그램을 도입하여 고객의 성향에 맞는 체계적인 관리체계를 도입한다면 브랜드 이미지 향상은 물론 고객 충성도를 높이는데 긍정적 작용을 할 것이다. 또한 고객의 요구에 귀 기울일 수 있는 고객의 소리 등의 시스템을 도입하 여 마케팅에 참고할 필요가 있다. 셋째, 지각된 가치가 고객 충성도 에 유의한 영향을 미치는 것으로 나타났고, 브랜드 이미지와 구전의 도를 매개 하는 것으로 나타났다. 따라서 지각된 가치는 헤어 살롱의 성장에 중요한 요인임을 확인할 수 있다. 살롱의 가치를 높이기 위해 서는 높은 단가보다는 기술과 서비스에 맞는 단가를 설정해야 하고, 고객들이 부담을 느끼지 않도록 만족감을 주어야 할 것이다. 시술 전 상담부터 금액 설정, 시술 내역 등의 구체적인 설명과 이해는 가장 기본이면서도 꼭 필요한 과정이다. 브랜드 이미지와 가치를 끌어 올 리는 것은 직원들의 인적서비스가 가장 큰 부분을 차지하므로 직원들 의 교육과 서비스에 심혈을 기울여야 할 것이다.

이렇듯 헤어 살롱의 브랜드 이미지와 고객들이 느끼는 지각된 가 치는 헤어 살롱의 발전과 성장을 위한 중요한 요인이다. 본 연구에서 는 헤어 살롱 이용 고객이 느끼는 브랜드 이미지, 지각된 가치, 고객 충성도에 대해 연구하여 헤어 살롱의 매출 향상과 발전에 기여하는 연구가 될 것으로 사료된다.

본 연구는 일부 지역의 서울, 경기 지역의 헤어 살롱 이용자를 대 상으로 표본구성을 했으므로 연구 결과를 일반화 시키는데 제한점을 가질 수 있다. 더욱 광범위한 지역을 대상으로 후속연구가 이루어지 길 기대한다.

\section{Acknowledgements}

This Research was supported by Seokyeong University in 2021.

\section{Author's contribution}

YJY and EJP contributed equally to this work. Y.Y.J and P.E.J. All surveys were designed by YJY and EJP. The collected questionnaire was written by YJY. And EJP analyzed collected data using the SPS program. YJY wrote the manuscript with assistance from EJP.

\section{Author details}

Yi-Ju Yeo (Profesor), Department of Beauty Design, Shin Ansan University, 135, Shin Ansan Deahak-ro, Danwongu, Ansan-si, Gyeonggi-do, 15435, Korea; Eun-Jun Park (Profesor), Department of Hair and Makeup Design, Colege of Beauty Art, Seokyeong University, 124 Seogyeong-ro, Seongbuk-gu, Seoul 02713, Korea.

\section{References}

Choi JH, Jang MY, Park EJ. Effects of perceptual value on the relationship between service quality and user satisfaction in hair salon. Journal of the Korean Society of Cosmetology, 25: 1221-1228, 2019.

Choi SI, Ahn JS, Lee SB. The effects of the selective attributes of coffee shop on perceived value and customer loyalty. Journal of Tourism and Leisure Research, 27: 319-340, 2015.

Lee BR, Hwang GVNR. A study on the effect of promotion service quality and perceived value of hair salon on repurchase intention. Journal of Beauty Art Management, 8: 167-176, 2014.

Jeong $\mathrm{BD}$, Kim JH. The effect of service quality and brand image of overseas direct purchase on perceived value, satisfaction and purchase intention. The e-Business Studies, 21: 3-18, 2020.

Jo HJ, Park EJ. The effects of brand assets on the relationship between the brand image and customer satisfaction. Journal of Korean Beauty Society, 25: 493-502, 2019.

Jo HN, Kim, YJ, Yang DH. A study on the influence of service quality to brand image and perceived value as perceived by dessert cafe consumers. Culinary Science and 
Hospitality Research, 25: 136-144, 2019.

Jung JH, Lee SB. A study on the selection motivation of environment-friendly foodon the perceived value, consumer attitude, and customer loyalty. International Journal of Tourism and Hospitality Research, 30: 211226, 2016.

Kang CK, Park YR. Impact on the quality of service perceived brand image and loyalty of hospital. The Academy of Customer Satisfaction Management, 18: 83-97, 2016.

Kim HJ, Oh TS, Yang EJ. Effects of customers' perception of VMD on brand image and brand reliability: focusing on domestic beauty salons. The Korean Society of Design Culture, 21: 243-252, 2015.

Kim HS, Kim YS. Effects wine bar's brand image on guest satisfaction, loyalty, revisit intention. The Journal of the Korea Contents Association, 10: 433-443, 2010.

Kim JA, Oh YK. Purchase behavior and satisfaction of onlineonly brand cosmetics. Asian Journal of Beauty and Cosmetology, 16: 32-41, 2018.

Kook HR, Na HY, Kim SH. The effects of nonverbal communication on customer trust and customer loyalty in hair and beauty service providers. Journal of the Korean Society of Cosmetology, 22: 1016-1025, 2016.

Lee $\mathrm{BH}, \mathrm{Na}$ Y. The causal relationship between experience marketing, perceived value, brand attitude, and behavior of hair shops. Journal of the Korean Society of Beauty and Art, 22: 133-151, 2021.

Lee EK, Han JH, Yang EJ. Effects of preferred hair beauty companies' brand images on purchase intention: in special reference to Juno Hair and Park Seung Chol Hair Studio. Journal of the Korean Society of Cosmetology, 21:
1084-1092, 2015.

Lee $\mathrm{HJ}$, Jin YM. The effects of awareness of the franchise hair salons on the brand-image and the satisfaction of the Franchise hair salons. Journal of the Korean Society Design Culture, 21: 577-588, 2015.

Lee HW, Kim YM. Structural relationship among factors affecting game attendance, perceived value, spectating satisfaction, spectating commitment, revisit intention and word of mouth intention of professional soccer spectators. Journal of Sport and Leisure Studies, 77: 145-164, 2019.

Lee SI. The effect of local tourist restaurant selection attributes on perceived value, customer satisfaction and revisit intention: focused on Gwangju area. Journal of Hotel \& Resort, 18: 331-350, 2019.

Lyu M. A study on the influence of design identity of Korean cosmetics industry in China on brand image, brand awareness, and brand loyalty, intention of use. The Treatise on The Plastic Media, 21: 250-258, 2018.

Oh YJ. Influence of a cosmetic company's eco-friendly activities on consumers' purchase intention through the mediating effects of perceived image. Asian Journal of Beauty and Cosmetology, 19: 149-167, 2021.

Song MS. What semiotic values do cosmetics consumers consume?: analysis of cosmetic brand reputation and brand selection attributes using text mining. Asian Journal of Beauty and Cosmetology, 19: 263-275, 2021.

Woo YS, Park EJ. Effect relationship of consumer perception, satisfaction and word-of-mouth intention about products sold at hair shop. Journal of the Korean Society of Cosmetology, 23: 1125-1132, 2017. 


\section{국문초록}

\section{헤어 살롱의 브랜드 이미지와 고객 충성도의 관계에서 지각된 가치의 매개효과}

여이주 ${ }^{1}$, 박은준 $^{2 *}$

${ }^{1}$ 신안산대학교 뷰티디자인과, 경기도 안산시, 한국

${ }^{2}$ 서경대학교 헤어메이크업디자인학과, 서울, 한국

목적: 본 연구는 헤어 살롱 브랜드 이미지와 지각된 가치, 고객 충성도의 관계를 알아보고, 헤어 살롱 브랜드 이미지와 고객 충성도 의 관계에서 지각된 가치의 매개효과를 파악하여 브랜드 이미지와 지각된 가치의 중요성을 강조하고 전문적인 헤어 살롱의 발전과 매출 향상을 위해 필요한 기초 자료를 제공하여 헤어 살롱 브랜드의 경쟁력을 높이는데 목적이 있다. 방법: 헤어 살롱을 이용하는 성인 남녀를 대상으로 설문지법을 통해 수집된 자료 534 부는 SPSS 22.0 을 사용하여 빈도분석, 신뢰도분석, 요인분석, 회귀분석, 매 개회귀분석을 실시하였다. 결과: 연구결과 브랜드 이미지가 지각된 가치와 고객 충성도에 유의미한 영향을 미치는 것으로 나타났 고, 지각된 가치는 고객 충성도에 유의미한 영향을 미쳤으며, 지각된 가치는 브랜드 이미지와 고객 충성도의 관계를 부분 매개하는 것으로 나타났다. 결론: 헤어 살롱의 브랜드 이미지에 긍정적인 효과를 줄 수 있는 요소들을 마케팅 해야 하며, 살롱의 가치를 높이 기 위해서 높은 단가보다는 기술과 서비스에 맞는 단가를 설정하고, 고객들이 부담을 느끼지 않도록 만족감을 주어야 할 것이다.

핵심어: 헤어, 살롱, 브랜드 이미지, 지각된 가치, 고객 충성도

본 연구는 2021학년도 서경대학교 교내연구비 지원에 의하여 이루어졌음.

\section{참고문헌}

강천국, 박유리. 병원의 지각된 서비스품질이 브랜드 이미지 및 충성도에 미치는 영향. 고객만족경영연구, 18: 83-97, 2016.

국혜란, 나해윤, 김서희. 헤어미용서비스 제공자의 비언어적 커뮤니케이션이 고객신뢰와 고객충성도에 미치는 영향. 한국 미용학회지, 22: 1016-1025, 2016.

김진아, 오윤경. 온라인전용 브랜드 화장품의 구매행태와 만족도. 아시안뷰티화장품학술지, 16: 32-41, 2018.

김혁수, 김연선. 와인 바의 브랜드 이미지가 고객만족, 충성도, 재방문 의도에 미치는 영향. 한국콘텐츠학회논문지, 10 : 433-443, 2010.

김현지, 오태식, 양은진. 소비자의 $\mathrm{VMD}$ 지각이 브랜드이미지와 브랜드신뢰에 미치는 영향. 한국디자인문화학회지, 21 : 243-252, 2015.

려맹언. 중국 내 한국 화장품 기업의 디자인 아이덴티티가 브랜드 이미지, 브랜드 인지도, 고객 충성도, 이용의도에 미치는 영향에 관한 연구. 조형미디어학, 21: 250-258, 2018.

송만석. 화장품 소비자는 어떤 기호가치로 소비를 하는가?: 텍스트 마이닝을 이용한 화장품 브랜드 평판과 브랜드 선택속 성 분석. 아시안뷰티화장품학술지, 19: 263-275, 2021.

오유진. 화장품 기업의 친환경활동이 지각된 이미지를 매개로 화장품 구매의도에 미치는 영향. 아시안뷰티화장품학술지, 19: 149-167, 2021.

우연수, 박은준. 헤어샵에서 판매하는 제품에 대한 소비자인식과 만족도 및 구전의도의 영향관계. 한국미용학회지, 23: 1125-1132, 2017.

이보람, 황금빛누리. 헤어살롱의 촉진서비스품질과 지각된 가치가 재구매의도에 미치는 영향. 미용예술경영연구, 8: 167176, 2014. 
이보현, 나윤영. 헤어숍의 경험마케팅, 지각된 가치, 브랜드 태도, 행도의도 간의 인과관계. 한국인체미용예술학회지, 22 : 133-151, 2021.

이승익. 향토관광음식점 선택속성이 지각된가치와 고객만족 및 재방문의도에 미치는 영향: 광주지역 중심으로. 호텔리조 트연구, 18: 331-350, 2019.

이은규, 한주희, 양은진. 헤어 미용기업의 선호브랜드별 브랜드이미지가 구매의도에 미치는 영향: 준오헤어와 박승철헤어 스투디오를 중심으로. 한국미용학회지, 21: 1084-1092, 2015.

이화웅, 김용만. 프로축구 관중의 경기관람요인과 지각된가치, 관람만족, 관람몰입, 재관람의도 및 구전의도의 관계. 한국 사회체육학회지, 77: 145-164, 2019.

이희진, 진용미. 프랜차이즈 미용실에 관한 인식이 프랜차이즈 미용실 브랜드 이미지와 만족도에 미치는 영향. 한국디자인 문화학회지, 21: $577-588,2015$.

정분도, 김지훈. 해외직접구매의 서비스품질과 브랜드이미지가 지각된가치, 만족도, 구매의도에 미치는 영향. $e-$ 비즈니스 연구, 21: 3-18, 2020.

정정희, 이수범. 친환경식품 선택 동기가 지각된 가치, 소비자 태도, 고객충성도에 미치는 영향에 관한 연구. 관광연구저 널, 30: 211-226, 2016.

조현진, 박은준. 헤어살롱의 브랜드이미지와 고객만족의 관계에서 브랜드자산의 매개효과. 한국미용학회지, 25: 493$502,2019$.

조희남, 김유진, 양동휘. 디저트 카페의 서비스 품질과 브랜드 이미지, 그리고 지각된 가치 간의 영향 관계 검증. 한국조리 학회지, 25: 136-144, 2019.

최성일, 안정석, 이수범. 커피전문점 선택속성이 지각된 가치와 고객충성도에 미치는 영향에 관한 연구. 관광레저연구, 27: 319-340, 2015.

최정하, 장미여, 박은준. 헤어살롱의 서비스 품질과 이용만족의 관계에서 지각가치의 매개효과. 한국미용학회지, 25 : 1221-1228, 2019. 


\section{中文摘要}

\section{感知价值在美发店品牌形象与顾客忠诚关系中的中介作用}

余怡周 ${ }^{1}$, 朴銀俊 $^{2 *}$

1新安山大学美容设计科, 京畿道鞍山市, 韩国

2西京大学美容艺术学科, 首尔, 韩国

目的：本研究通过检验和识别美发沙龙的品牌形象、感知价值和顾客忠诚之间的中介作用，强调品牌形象和感知 价值。旨在通过提供专业美发沙龙发展和提高销售所需的基础数据, 增强美发沙龙品牌的竞争力。方法: 美发 沙龙的成年男性和女性作为调查对象, 使用SPSS 22.0对通过问卷调查收集的534份数据进行频率分析、信度分 析、因子分析、回归分析和中介回归分析。结果: 结果表明, 品牌形象显著影响顾客感知价值和顾客忠诚。此 外, 感知价值显著影响顾客忠诚, 并部分中介了品牌形象与顾客忠诚之间的关系。结论: 对于美发沙龙来说, 营 销具有正面品牌形象效应的因素是必要的, 顾客应该感到满意和无负担。此外, 为了增加沙龙的价值, 应该为 技术和服务制定合适的单价，而不是更高的单价。

关键词: 头发, 沙龙, 品牌形象, 感知价值, 客户忠诚度 